\title{
Private Equity Impact on Corporate Innovation
}

\author{
Israel J. Hersh
}

\begin{abstract}
This paper focuses on the influence of Private Equity (PE) firms on corporate innovation with the purpose of identifying opportunities such as new or enhanced strategies that PE firms would use to in order to increase the success rate of their acquisitions. The paper starts with a comprehensive literature review and creates a strong theoretical foundation about PE Leveraged Buyout (LBO) companies and their impact on corporate innovation. The methods used in this paper are the case study research, which is introduced to create theory [1] and the review-centric research approach of reviewing existing theory and research as well as for creating a new model of variables and relationships [2] that can be used to validate new hypotheses. The paper introduces a new model that is based on data collection from the review of existing theory and research. The model is a collection of variables that are categorized and linked together to depict new relationships that show the PE LBOs' influence on corporate innovation. The research also identifies inconsistency in the existing research literature as an opportunity for future research. The research is limited by the duration of a semester which is the timeframe allotted to complete the research work. Develop understanding of the reasons some LBOs fail and strategies that will help PE firms increase the success rate of their investments and create a win-win scenario for investors, employees, and the entire value chain. This paper new concepts and ideas are completely derived from the theoretical foundation and the professional experience of the author.
\end{abstract}

Index Terms-Corporate Innovation; Leveraged Buyouts; Private Equity; Short-Termism.

\section{INTRODUCTION}

In October 2007, two Private Equity (PE) firms, Silver Lake Partners (SLP) Investment Partners, LLC and TPG Capital acquired Avaya, a technology company, for $\$ 8.3$ billion. In the press release, Lou D'Ambrosio, president and CEO was quoted: "Today marks the beginning of an exciting new era for Avaya." stating that as a privately held company that is owned by SLP and TPG, Avaya has a unique opportunity to advance its strategy and increase its innovation [3]. On January 17, 2017, Avaya filed for Chapter 11 bankruptcy to reduce its debt load of about $\$ 6.3$ billion [4]. Nine plus years of wealth destruction, facility closures, and loss of livelihood for thousands of vendors and employees raise the question of why Avaya failed to deliver on Mr. D'Ambrosio's prediction of increased innovation and responsiveness.

The relationship between leadership, long-term strategy, corporate culture, innovation, and their influence on business success are well researched and many publications are available on this topic [5]-[7]. The PE Leveraged Buyout

Published on April 30, 2018.

Israel J. Hersh is with the Technology Management Department, University of Bridgeport, Bridgeport, CT 06604 USA, (e-mail: ihersh@my.bridgeport.edu).
(LBO) segment, on the other hand is different. An LBO is a financial transaction where the PE buys all the equity of a company and removes it from the public markets. The purchase transaction is usually $10-15 \%$ cash and $85-90 \%$ loan [8], [9]. Thus, the PE is leveraging the acquired company with the belief that the business profit will cover the loan payments. Such acquisitions bring 4 types of changes to the acquired organization: (1) change in ownership; (2) change in capital ownership; (3) change in assets; (4) organization change. Changes in ownership and capital positively affect the senior management team and motivates it to align with the investors' objectives. In theory, post buyout, senior managers are rewarded in the form of significant stock options. As such, they start operating as owners, making decisions that increase efficiency [10] and add value to the organization. Additionally, post the buyout, business control is shifted to a few partners in the PE organization that closely monitor [10]-[13] the senior managers to ensure that the investors' objectives are executed correctly. The strategy of the PE partners is to reduce operational cost to enable the business to pay its large debt [14]-[16], including closing or selling lines of business that do not perform, reducing research and development (R\&D) spend [17]-[19], reducing headcount, and layers of management [20]-[23].

Significant research was done in this industry segment and the results are quite inconsistent [24]. Some researchers suggest that the innovation activities increase post-LBO [14], [25]-[28]. Others suggest that due to the need to service the high debt and generate the high returns that the investors expect, PE LBOs focus on short-term gains through increased efficiency and reduced R\&D spend which impact corporate innovation [14], [29]-[31]. This paper is based on review-centric research of over 60 articles that span over the last thirty years. It identifies, extracts, and categorizes a long list of variables that are then linked together to create a novel model that can be tested against new hypotheses. The inconsistencies in the existing research literature suggest that there are future research opportunities in this area.

\section{RESEARCH METHOD}

The research methods that are used in this study are the case study research that are based on the principles outlined by [1] and the review-centric research that are based on the concepts outlined by [32]. This literature review spans over a thirty-year period and provides a comprehensive literature review on the PEs impact on corporate innovation. The theoretical foundation of this paper is based on over 60 articles that were reviewed. The articles came from journals such as: Small Business Economics, Management International Review, The Journal of Business, The Journal 
of Finance, Journal of Financial Economics, Journal of Corporate Finance, Financial Management, The American Economic Review, International Journal of Business Studies, The Review of Financial Studies, The Academy of Management Review, The Academy of Management Executive, and others. The research attempts to identify inconsistencies in the existing research literature as an opportunity for future research. This is achieved via exploratory analysis and qualitative research. The contribution of the study is intended to review, categorize, and summarize the theoretical and empirical knowledge that should inspire new discussions and directions for future research activity.

\section{CORPORATE INNOVATION}

The literature is quite inconsistent about the entrepreneurial activities and more specifically about their impact on the corporate innovation of their LBOs [24]. While some argue that LBOs are focused on efficiency improvement there are studies that provide different point of view. One research emphasizes the role of the leadership of the LBOs that includes entrepreneurial minds that drive innovation [26]. Another research tracks the innovative activities of the LBOs by studies their patent filing over the first few year of post-LBO [25]. Similar research indicates that while the focus is still on efficiency improvement, LBOs find a way to do both incremental and radical innovation [33]. Some LBOs focus on a different entrepreneurial activity such as growth through acquisitions rather than organic innovation [27] while another study shows that the LBO ownership is well aware of timing the market for their investment exit and therefore has more tolerance for risk, thus willing to pursue risky innovative activities [28]. My view is that innovation activities in LBOs are more likely to take place in the earlier stage of the ownership. These activities are conditioned by other priorities such as paying the debt and funding the innovative projects. As the time to exit the investment is approaching, the appetite of the ownership for investing in innovation is diminished.

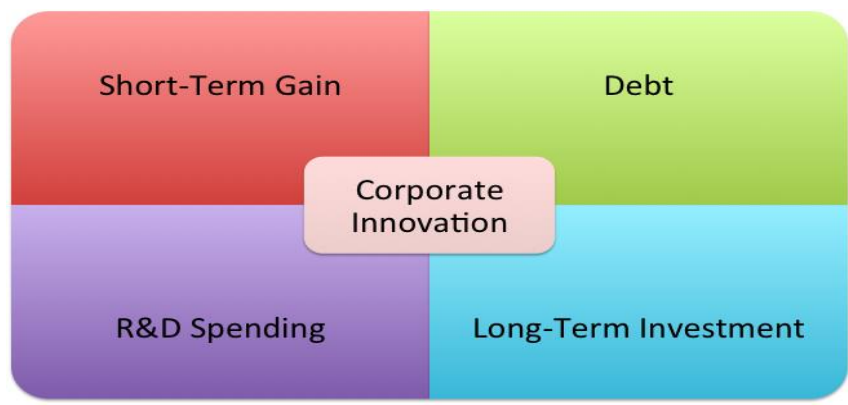

Fig. 1. LBOs Corporate Innovation is influenced by Short-Term Gain, Debt, R\&D Spending, and Long-Term Investment.

\section{SHORT-TERM GAIN}

PE firms acquire public (typically) companies and take them private through an investment of $10-15 \%$ equity and $85-90 \%$ debt deal. Their objective is to generate large gains by flipping the investment and exiting after an average ownership of 5 years [9], [29]. The PEs promote activities that generate short-term profits to service the debt while long-term investment take lower priority [14]. The high pressure and the strong monitoring that the PE applies on the LBO management, influences the management team to develop a short-term view which in turns hurts innovation [30]. The PE ownership is mainly concerned about servicing the debt and focuses the LBO management on efficiency and cash flow generation while sacrificing long-term growth through innovation [31], [34]. Although the literature provides sufficient evidence that show post-LBO negative impact on innovation, there is evidence that some investments in R\&D occur as long as the risk is low and the completion of the projects is within their investment horizon.

\section{A. Executive Compensation}

Private Equities align executives with their investment objectives by awarding them large equity positions and high compensation that are influenced by the company performance. The executives are therefore focused on shortterm gains and avoid making risky decision such as investing in long-term projects [10],[35],[36]

\section{B. Investors Return}

Investors invest in PE funds because they expect to receive a higher return than they would receive from a public equity investment [37]. The PE funds have an investment horizon of 5-8 years after which the capital is returned to the investors [9].

\section{Increase Efficiency}

Although some researchers suggest that the efficiency in the LBOs does not improve post-LBO [38], it is quite evident that the large debt that LBOs incur forces managers to focus on increasing efficiency to better serve the debt and to obtain short-term gains [10].

\section{Performance Measurement}

LBOs' boards are made of PE partners that heavily monitor the LBO's management. Such monitoring influences management to exhibit short-term behavior [10] [13]. Performance measurement influences human behavior and therefore managers are motivated to maximize the results that LBO's accounting is expecting [39].

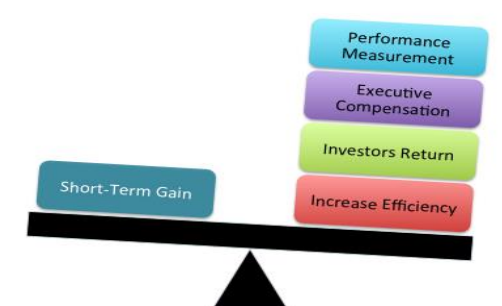

Fig. 2. Short-Term Gain decisions are influenced by the ownership's desire for high returns that are achieved by alignment management with the ownership's objectives through incentives and close monitoring. This strategy changes behavior and focus of management to generate short-term gains through efficiencies. 


\section{DEBT}

The commitment to service the high debt is a major driver for the behavior and the practices of the LBOs. Due to the debt, the PE ownership plays an important role in monitoring and motivating the LBO managers [12]. The objective of servicing the debt is forcing management to prioritize technology projects, cut the low priority ones, sell assets, reduce cost, and restructure the organization to gain more accountability and control [16]. Future cash is directed to service the debt [15] and pressure is applied on management to focus on short-term tactical activities [40]. Many LBOs would wait until the debt reaches low levels before implementing strategic projects [20] and some evidence is there that there is willingness to grow the business [11]. Servicing the debt is critical since the creditors are demanding and will take equity positions in the LBOs if their obligations are not met. Survival of the business is the highest priority and is the foundation on which longer term activities should be built.

\section{A. Tax Benefits}

One of the reasons PEs are leveraging an acquired company is to take advantage of the tax laws and receive tax incentives [41]. Another benefit is the ability to deduct the high interest payments through the enhanced corporate tax deductions [10].

\section{B. Increase Investor ROI}

PE investors expect higher returns than public equity investors. The entry level is high and the outcome is risky. They demand returns in a short horizon, which is faster than their current rate of growth [10]. PEs accomplish it by utilizing a philosophy of levering the acquired companies as much as possible in order to get the highest return to the investors [42].

\section{Low Leverage Company}

When acquiring a company, PEs evaluate candidate firms utilizing financial models to identify low-leveraged companies as acquisition targets to help them leverage the acquisition and be able to still navigate through financial downturns [43]. Likewise, PE firms who wish to implement an entrepreneurial strategy in order to turnaround a firm, will either find a low leveraged firm or implement one in the funding of the buyout [26].

\section{Liquidity}

LBO targets must have high liquidity as a condition to become an LBO target. [43] LBOs must service the debt and therefore must have a high level of liquidity [44]

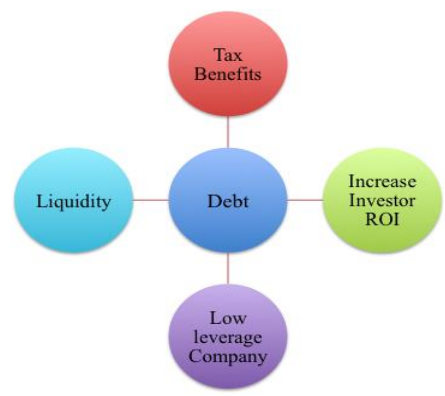

Fig. 3. Creating a large Debt is the feasible for companies that are lowleveraged and liquid enough to carry high level of debt. The other factors include increased ROI for investors and receiving large tax benefits.

\section{R\&D SPENDING}

It is clear that the literature is providing a mixed view of the role of LBOs in impacting R\&D spending [45]. On one hand, some researchers indicate that the LBOs may not have the resources to focus on both the short-term and the longterm activities or that the $R \& D$ investments may be postponed, reduced or jeopardized [46] [18], [19]. On the other hand, some researcher state that some LBOs may stimulate $\mathrm{R} \& \mathrm{D}$, or that there is no evidence that LBOs invest less than other firms in R\&D [17], [47]. The subject is obviously controversial and more research is required to better understand how PE firms manage the LBOs. It is very possible that not all LBOs have the same strategies, time horizon, investment philosophies, and management practices.

\section{A. Competitive Advantage}

Critics assert that America is falling behind due to a reduction in its competitive advantage. This is mostly due to restructuring where managers focus on bottom line and short-term results rather than innovating through investments in $R \& D$ [23]. When funding is scarce, $R \& D$ projects are suspended and mostly affecting technology or product firms in $\mathrm{R} \& \mathrm{D}$ intensive industries due to the loss of their competitive edge [48]. Managers' decision to invest in $\mathrm{R} \& \mathrm{D}$ is clearly the most appropriate investment decision they make. Such investments help organizations develop new products and technology that are essential to the future competitive advantage a company must possess in order to be successful [7].

\section{B. Industry}

Industries such as biotechnology, pharmaceutical or computer are considered $R \& D$ intensive while retailing is not. The size of $\mathrm{R} \& \mathrm{D}$ spend has a different impact on companies in R\&D intense industry than on companies in low $R \& D$ intensity industry. In $R \& D$ intense industries, a small reduction in $R \& D$ spend could be devastating while meaningless in other industries [17]. High debt will even force firms in $R \& D$ intensive industries to cut expenses despite the risk of not surviving as a business [49].

\section{Future Profits}

The firm size, the amount of debt, and the industry type affect the influence of $R \& D$ investments on the future profits of a company [50]. When senior managers invest in R\&D they are investing in the future of their company and their personal future profits. It is therefore unlikely that they will reduce R\&D spending and negatively impact their future benefits in order to obtain short-term gains [23]. While some researchers assert that capital expenditure generate larger future benefits than $R \& D$ spending does, it is quite evident that both types of investments generate future corporate profits [51].

\section{Debt Level}

High Debt is common at LBOs. High debt level negatively influences the R\&D spending of an organization [49], [52], [53]. 


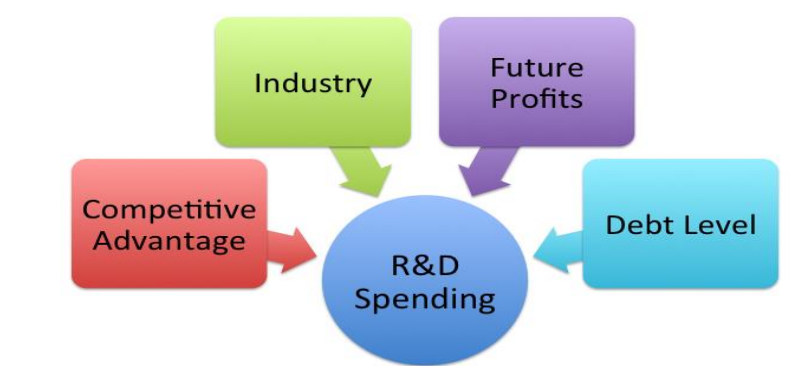

Fig. 4. R\&D spending is driven by the objective of remaining profitable in the long-term. High debt level negatively influences R\&D Spending and intensive $R \& D$ industries must invest in $R \& D$ to gain competitive advantage.

\section{LONG-TERM INVESTMENT}

Short-term cash flow pressures influence the behavior of LBOs. They focus on short-term activities that are designed to increase cash flow and either reduce or eliminate longterm investments in technology [49]. LBOs place transactional leaders in the helm of their companies. Transformational leadership will be conflicted in such environment due the long-term nature of their management philosophy [5]. Long-term and short-term investment decisions are conflicting in LBOs where short-term gains are more important [54] and could be generating even a higher gain if long-term investments like $\mathrm{R} \& \mathrm{D}$ are cut back [55] and replaced by less risky and more affordable shortterm projects [56]. Some research indicates that despite the short-term objectives of generating cash flow, managers still take a long-term view and continue to invest in future projects [57]. My opinion is that there must be a balanced strategy (short-term and long-term) and that the LBO could be at a risk of failure if the entire attention is on short-term gains. In an accelerated technology era, not paying sufficient attention to future technology investments could lead to an irreversible negative outcome.

\section{A. Acquisitions}

Prior research is on how acquisitions are impacting R\&D spend is inconclusive. Some suggest that acquisitions reduce $R \& D$ input and output, impacting future performance [58] while others suggest that there is no impact on R\&D spend [52].

\section{B. Financial Controls}

PE partners impose tight financial controls in their LBOs [16] that are typically associated with the high debt levels and discourage long-term investments [53]. Business managers are managed by objectives and their performance is evaluated on achieving them [18].

\section{Short-Term Investment Horizon}

PEs investment horizon is under seven years. Post-LBO practices related to human resources (HR) indicate the ownership's intentions. Investing in long-term HR practices indicates whether the investment horizon is long or short [59]. PEs are not inclined to invest in management practices in their LBOs because of the benefits will not be realized during the investment horizon [31]. Managers tend to reduce or delay long-term projects knowing that they will not be in the same role at the time the outcome of their actions is evident [18].

\section{Uncertainty}

Acquisitions like PE LBOs create uncertainty which is a strong reason to why corporate management is reluctant making long-term commitments such as employment or future investments [18]. Building competitive advantage through investments in continued innovation are weighed against activities that increase short-term profits [54] and since investors are actively looking for quick gains, managers are inclined to invest in in safe, short-term projects [56].

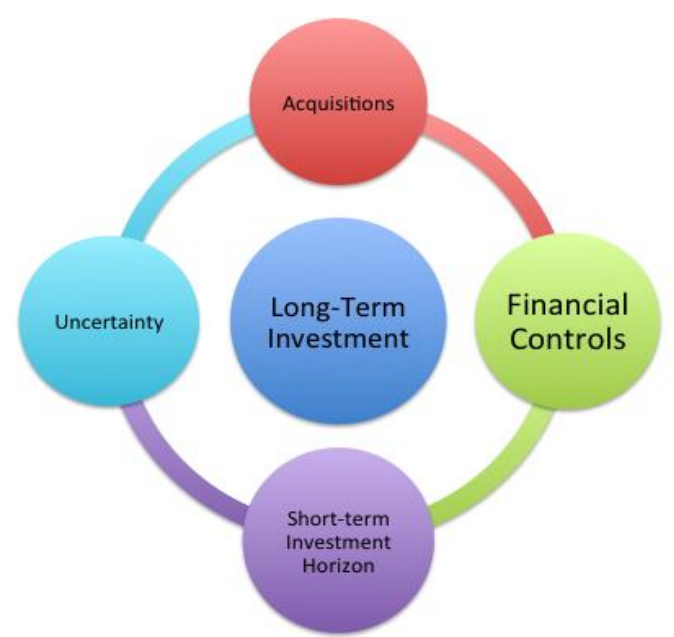

Fig. 5. Long-term investment is influenced by acquisitions, financial controls, short-term investment horizon, and uncertainty.

\section{RESULTS AND DISCUSSION}

PE firms acquire public (typically) companies and take them private through a leveraged buyout. Their objective is to generate large gains in a short period of ownership, which is 5 years in average [9], [29]. The data model that is introduced in this paper shows the factors and relationships that influence the decisions and activities in PE LBO firms that ultimately impact corporate innovation. The literature is quite inconsistent about the impact of PE firms on corporate innovation [24]. A number of researchers suggest that the innovative activities of the LBOs are either not impacted by the PE firms or improve post LBO [25], [26], [28] despite the focus on efficiency improvements [33] while Zahra [27] suggests that some LBOs emphasize a different entrepreneurial activity such as growth through acquisitions rather than organic innovation. This research shows that four significant factors are negatively influencing Corporate Innovation.

The first one is Short-Term Gains where the PE firms promote activities that generate short-term profits to service the debt while long-term investment take lower priority [14]. The high pressure and the strong monitoring that the PE firm applies to the LBO management, influences the management team to develop a short-term view which in turns hurts innovation [30]. The PE ownership is mainly concerned about servicing the debt and focuses the LBO management on increasing efficiency and generating cash flow while sacrificing long-term growth through innovation [31], [34]. Although the literature provides sufficient 
evidence that shows post-LBO negative impact on innovation, there is evidence that some investments in $R \& D$ occur as long as the risk is low and the completion of the projects is within their investment horizon. Short-term gains are influenced by four sub-factors: (1) Executive Compensation: Private Equities align executives with their investment objectives by awarding them large equity positions and high compensation that are influenced by the company performance. The executives are therefore focused on short-term gains and avoid making risky decision such as investing in long-term projects [10], [35], [36]; (2) Investors Return: Investors invest in PE funds for two reasons. First one, they expect to receive higher returns than they would have received from a public equity investment [37] and the second one is the investment horizon, where the PE funds have an investment horizon of 5-8 years after which the capital is returned to the investors [9]; (3) Increased Efficiency: Although some researchers suggest that the efficiency in the LBOs does not improve post-LBO [38], it is quite evident that the large debt that LBOs incur forces managers to focus on increasing efficiency to better serve the debt and to obtain short-term gains [10]; (4) Performance Management: LBOs' boards are made of PE partners that heavily monitor the LBO's management. Such monitoring influences management to exhibit short-term behavior [10], [13], [39].

The second factor that influences corporate innovation is the high debt where the commitment to service it is the major driver for the short-term behavior and practice of the LBO. PE partners monitor, motivate, and apply pressure on the LBO managers [12], [40] to prioritize technology projects, cut the low priority ones, sell assets, reduce cost, and restructure the organization to gain more accountability and control [16] while future cash is directed to service the Debt [15]. Many LBOs wait until the Debt reaches a low level before implementing strategic projects [20] and starting to implement business growth activities [11]. Debt is influenced by four sub-factors: (1) Tax Benefits: One of the reasons PEs are leveraging an acquired company is to take advantage of the tax laws and receive tax incentives [10], [41]; (2) Increase Investor ROI: PE investment requires larger capital and is riskier than investing in the public sector, which is why investors expect higher returns in a short-time horizon that is faster than their current rate of the firm's growth [10]. This is the reason PE firms maximize leveraging the acquired companies [42]; (3) Low Leveraging Company: When acquiring a company, PE firms evaluate investment candidates (firms) utilizing financial models to identify low-leveraged companies as acquisition targets that could be highly leveraged and still able to navigate through financial downturns [26], [43]; (4) Liquidity: LBO targets must have high liquidity and the ability to service the Debt as conditions to become LBO targets. [43], [44]

The third factor that influences corporate innovation is $R \& D$ spending. The literature is inconsistent about the influence of LBOs on $R \& D$ spending [45]. Some researchers indicate that the LBOs may not have the resources to focus on both the short-term and the long-term activities or that the R\&D investments may be postponed, reduced or jeopardized [18], [19], [46] while others state that R\&D
Spending is in par with other companies that some LBOs may even stimulate $\mathrm{R} \& \mathrm{D}$ [17], [47]. $R \& D$ spending is influenced by four sub-factors: (1) Competitive Advantage: Critics assert that due to restructuring where managers focus on bottom line and short-term results rather than innovating through investments in $\mathrm{R} \& \mathrm{D}$, the American competitive advantage is declining. [23]. Companies in R\&D intensive industries are the ones mostly affected by luck of funding that is required to keep their competitive edge [48] Investments in $\mathrm{R} \& \mathrm{D}$ enable organizations develop new products and technology that are essential to their future Competitive Advantage and success [7]; (2) Industry: Industries such as biotechnology, pharmaceutical or computer are considered $R \& D$ intensive industries while retailing is not. The size of $R \& D$ spending has a higher impact on companies in R\&D intense industry where a small reduction in $R \& D$ spending could be devastating while meaningless in other industries [17]. Due to high Debt, even firms in R\&D intensive industries are forced to cut expenses despite the risk of not surviving as a business [49]; (3) Future Profits: It is common sense that when senior managers invest in $R \& D$ they are investing in the future of their company and their personal future profits. It is therefore unlikely that they will reduce $R \& D$ spending and negatively impact their future benefits in order to obtain Short-term gains [23]. However, the firm size, the debt size and the industry type affect the influence of $R \& D$ investments on the company's future profits [50]. While some researchers assert that capital expenditure generate larger future benefits than $R \& D$ spending does, it is quite evident that both types of investments generate future corporate profits [51].; (4) Debt Level: High debt is common at LBOs and negatively influences the $R \& D$ spending of an organization [49], [52], [53]. More research is required to better understand how $\mathrm{PE}$ firms manage the LBOs. It is very possible that not all LBOs have the same strategies, time horizon, investment philosophies, and management practices.

The fourth factor that influences corporate innovation is long-ierm investment. Short-term financial pressure influences LBOs' behavior to increase cash flow while either reducing or eliminating Long-term investments in technology [49], [54], [55] replacing them by less risky and more affordable short-term projects [56]. PE firms place transactional leaders in the helm of their companies because transformational leadership will be conflicted in such environment due the long-term nature of their management philosophy [5]. Research is inconsistent where some research indicates that despite the short-term objectives of generating cash flow, managers are still inclined to take a long-term view and continue to invest in future projects [57]. Long-term investment is influenced by four subfactors: (1) Acquisitions: Research about the influence of acquisitions on $R \& D$ spending is inconclusive. Some suggest that acquisitions reduce $\mathrm{R} \& \mathrm{D}$ input and output, impacting future performance [58] while others suggest that there is no impact on $R \& D$ spending [52]; (2) Financial Controls: PE partners impose tight financial controls in their LBOs [16] that are typically associated with the high debt levels and discourage Long-term investments [53]. Business managers are managed by objectives that influence their 
performance evaluation [18]; (3) Short-term investment horizon: Investing in long-term $\mathrm{HR}$ practices indicates whether the investment horizon is long or short-term [59]. $\mathrm{PE}$ firms are not inclined to invest in the LBO's management practices because the benefits will not be realized during the short-term investment horizon [31]. Managers tend to reduce or delay long-term projects knowing that they will not be in the same role at the time when the outcome of their actions is evident [18]; (4) Uncertainty: Acquisitions like PE LBOs create uncertainty which is why corporate management is reluctant making long-term commitments on employment or future investments [18]. Building competitive advantage through investments in continued innovation is weighed against activities that increase short-term profits [54] and since investors are actively looking for quick gains, managers are inclined to invest in in less uncertain, short-term projects [56].

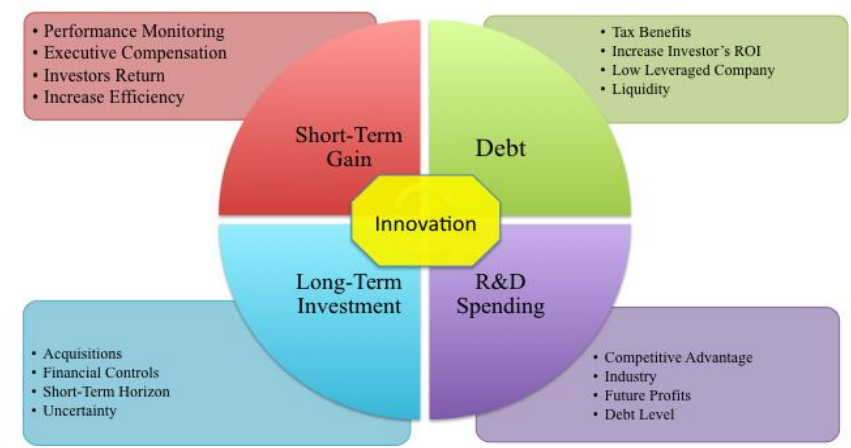

Fig. 6. PE LBOs variables that are impacting corporate innovation

\section{CONCLUSION}

The research utilizes case study and review-centric research methods to create a strong theoretical foundation about PE LBOs and their impact on corporate foundation. Twenty-one factors that influence corporate innovation were extracted, categorized, and linked together to create a novel model that illustrates the factors and the relationships that influence corporate innovation in PE LBOs. The model explains the strategies and processes that PE firms use to create wealth. Funding of the acquisitions identifies the first set of factors that influence the reason for leveraging the acquired companies. Debt and equity financing influence the short-termism behavior of LBOs that impacts on R\&D spending and long-term investments. These factors ultimately influence corporate innovation and the future success of the LBO. The research also identifies inconsistencies in prior research that could provide opportunities for future research. The model can provide value to PE firms and to the entire value chain of the LBOs. More research is required to better understand how successful LBOs operate in comparison to the failed on to suggest methods and processes that could provide a formula to success in this industry. The inconsistencies that were discovered during the research provide further opportunities to research the field and to validate new hypotheses that can help increase the rate of successful LBOs, maximize the investors' return, and protect the livelihood of the employees and the value chain.

\section{REFERENCES}

[1] Eisenhardt, K.M., Building Theories from Case Study Research. The Academy of Management Review, 1989. 14(4): p. 532-550.

[2] LePine, J.A. and A. Wilcox-King, Editors' Comments: Developing Novel Theoretical InsightFrom Reviews of Existing Theory and Research. The Academy of Management Review, 2010. 35(4): p. 506509.

[3] Lynn Newman, M.R., Avaya, 908-953-8692, lynnnewman@avaya.com,Reporter, Silver Lake and TPG Capital Complete Acquisition of Avaya, I. Avaya, Editor. 2007, Avaya Inc., 4655 Great America Parkway, Santa Clara, CA 95054-1233 USA: BASKING RIDGE, N.J.

[4] Deborah Lewandowski, C.C., North America, 630-245-2720, deblewan@avaya.com, Avaya Inc. Files for Chapter 11 Protection, I. Avaya, Editor. 2017, Avaya Inc., 4655 Great America Parkway, Santa Clara, CA 95054-1233 USA.

[5] Bass, B.M. and B.J. Avolio, Transformational Leadership and Organizational Culture. Public Administration Quarterly, 1993. 17(1) p. 112-121.

[6] Jeroen PJ, d.J.D.H., D.,N, How leaders influence employees' innovative behaviour. European Journal of Innovation Management, 2007. 10(1): p. 41-64.

[7] Barker, V.L. and G.C. Mueller, CEO Characteristics and Firm R\&D Spending. Management Science, 2002. 48(6): p. 782-801.

[8] John C Easterwood, A.S., Ronald F Singer, The impact of leveraged buyouts on strategic direction, in California Management Review;Berkeley. 1989. p. 30.

[9] Kaplan, S.N. and P. Stromberg, Leveraged Buyouts and Private Equity. The Journal of Economic Perspectives, 2009. 23(1): p. 121 146.

[10] Masulis, R.W. and R.S. Thomas, Does Private Equity Create Wealth? The Effects of Private Equity and Derivatives on Corporate Governance. The University of Chicago Law Review, 2009. 76(1): p. 219-259.

[11] Bertoni, F., et al., The different roles played by venture capital and private equity investors on the investment activity of their portfolio firms. Small Business Economics, 2013. 40(3): p. 607-633.

[12] Cotter, J.F. and S.W. Peck, The structure of debt and active equity investors: The case of the buyout specialist. Journal of Financial Economics, 2001. 59(1): p. 101-147.

[13] Amess, K. and M. Wright, Leveraged buyouts, private equity and jobs. Small Business Economics, 2012. 38(4): p. 419-430.

[14] Amess, K., J. Stiebale, and M. Wright, The impact of private equity on firms' patenting activity. European Economic Review, 2016. 86: p. $147-160$

[15] Bruining, H., E. Verwaal, and M. Wright, Private equity and entrepreneurial management in management buy-outs. Small Business Economics, 2013. 40(3): p. 591-605.

[16] Phan, P.H. and W.L.H. Charles, Organizational Restructuring and Economic Performance in Leveraged Buyouts: An Ex Post Study. The Academy of Management Journal, 1995. 38(3): p. 704-739.

[17] Zahra, S.A. and F. Michael, Will Leveraged Buyouts Kill U.S. Corporate Research \& Development? The Executive, 1991. 5(4): p. 7 21.

[18] Hitt, M.A., et al., The Market for Corporate Control and Firm Innovation. The Academy of Management Journal, 1996. 39(5): p. 1084-1119.

[19] Liebeskind, J., M. Wiersema, and G. Hansen, LBOs, Corporate Restructuring, and the Incentive-Intensity Hypothesis. Financial Management, 1992. 21(1): p. 73-88.

[20] Cumming, D., D.S. Siegel, and M. Wright, Private equity, leveraged buyouts and governance. Journal of Corporate Finance, 2007. 13(4): p. 439-460.

[21] Davis, S.J., et al., Private Equity, Jobs, and Productivity. The American Economic Review, 2014. 104(12): p. 3956-3990.

[22] Easterwood, J., A. Seth, and R. Singer, Limits on Managerial Discretion in Management Buyouts: The Effectiveness of Institutional, Market and Legal Mechanisms. Managerial and Decision Economics, 1997. 18(7/8): p. 645-666.

[23] Fox, I. and A. Marcus, The Causes and Consequences of Leveraged Management Buyouts. The Academy of Management Review, 1992. 17(1): p. 62-85.

[24] Link, A., C. Ruhm, and D. Siegel, Private Equity and the Innovation Strategies of Entrepreneurial Firms: Empirical Evidence from the Small Business Innovation Research Program. 2012, National Bureau of Economic Research, Inc.

[25] Lerner, J., M. Sorensen, and P. Strömberg, Private Equity and LongRun Investment: The Case of Innovation. Journal of Finance, 2011. 66(2): p. $445-477$ 
[26] Wright, M., R.E. Hoskisson, and L.W. Busenitz, Firm rebirth: Buyouts as facilitators of strategic growth and entrepreneurship. The Academy of Management Executive, 2001. 15(1): p. 111-125.

[27] Zahra, S.A., Goverance, Ownership, and Corporate Entrepreneurship: The Moderating Impact of Industry Technological Opportunities. The Academy of Management Journal, 1996. 39(6): p. 1713-1735.

[28] Ferreira, D., et al., Incentives to Innovate and the Decision to Go Public or Private. The Review of Financial Studies, 2014. 27(1): p. 256-300.

[29] Gompers, P., S.N. Kaplan, and V. Mukharlyamov, What do private equity firms say they do? Journal of Financial Economics, 2016. 121(3): p. 449-476

[30] Bertoni, F., Innovation in Private Equity Leveraged Buyouts. SSRN Electronic Journal, 2017.

[31] Humphrey, J.N.Y., T. Matthias, and D. Christoph, The Effect of Private Equity Ownership on Management Practices: A Research Agenda. Competition \& Change, 2014. 18(2): p. 164-179.

[32] LePine, J.A. and A. Wilcox-King, Developing novel theoretical insight from reviews of existing theory and research. Academy of Management Review, 2010. 35(4): p. 506-509.

[33] Wright, M., et al., Entrepreneurial Growth through Privatization: The Upside of Management Buyouts. The Academy of Management Review, 2000. 25(3): p. 591-601.

[34] Le Nadant, A.-L. and F. Perdreau. Do Private Equity Firms Foster Innovation? Evidence from French LBOs. in International Conference on Economics and Management of Networks (EMNet). 2011. Limassol, Cyprus.

[35] Kaufman, A. and E.J. Englander, Kohlberg Kravis Roberts \& Co. and the Restructuring of American Capitalism. The Business History Review, 1993. 67(1): p. 52-97.

[36] 36. Hoskisson, R.E., M.A. Hitt, and W.L.H. Charles, Managerial Risk Taking in Diversified Firms: An Evolutionary Perspective. Organization Science, 1991. 2(3): p. 296-314.

[37] Kaplan, S.N. and A. Schoar, Private Equity Performance: Returns, Persistence, and Capital Flows. The Journal of Finance, 2005. 60(4): p. 1791-1823.

[38] Bharath, S., A. Dittmar, and J. Sivadasan, Do Going-Private Transactions Affect Plant Efficiency and Investment? The Review of Financial Studies, 2014. 27(7): p. 1929-1976.

[39] Marginson, D. and L. McAulay, Exploring the Debate on ShortTermism: A Theoretical and Empirical Analysis. Strategic Management Journal, 2008. 29(3): p. 273-292.

[40] Zahra, S.A., Corporate entrepreneurship and financial performance: The case of management leveraged buyouts. Journal of business venturing, 1995. 10(3): p. 225-247.

[41] Newbould, G.D., R.E. Chatfield, and R.F. Anderson, Leveraged Buyouts and Tax Incentives. Financial Management, 1992. 21(1): p 50-57.

[42] Axelson, U., et al., Why Are Buyouts Levered? The Financia Structure of Private Equity Funds. The Journal of Finance, 2009. 64(4): p. 1549-1582.

[43] Singh, H., Management Buyouts: Distinguishing Characteristics and Operating Changes Prior to Public Offering. Strategic Management Journal, 1990. 11: p. 111-129.

[44] Evans, J., M. Poa, and S. Rath, The financial and governance characteristics of australian companies going private. International Journal of Business Studies, 2005. 13(1): p. 1-24.

[45] Chevalier, J.A., Do LBO Supermarkets Charge More? An Empirical Analysis of the Effects of LBOs on Supermarket Pricing. The Journal of Finance, 1995. 50(4): p. 1095-1112.
[46] Lowenstein, L., Management Buyouts. Columbia Law Review, 1985 85(4): p. 730-784

[47] Lichtenberg, F.R. and D. Siegel, The effects of leveraged buyouts on productivity and related aspects of firm behavior. Journal of Financial Economics, 1990. 27(1): p. 165-194

[48] Li, D., Financial Constraints, R\&D Investment, and Stock Returns. The Review of Financial Studies, 2011. 24(9): p. 2974-3007.

[49] Bruton, G.D. and E. Scifres, Leveraged Buyouts: Their Impact on R\&D Spending. MIR: Management International Review, 1992 32(1): p. 7-21.

[50] Ho, Y., et al., Size, Leverage, Concentration, and R\&D Investment in Generating Growth Opportunities. The Journal of Business, 2006 79(2): p. 851-876.

[51] Kothari, S.P., T.E. Laguerre, and A.J. Leone, Capitalization versus Expensing: Evidence on the Uncertainty of Future Earnings from Capital Expenditures versus R\&D Outlays. Review of Accounting Studies, 2002. 7(4): p. 355-382.

[52] Hall, B.H., E. Berndt, and R.C. Levin, The Impact of Corporate Restructuring on Industrial Research and Development. Brookings Papers on Economic Activity. Microeconomics, 1990. 1990: p. 85 135

[53] Harrison, J.S., LBOs Slash R\&D: So What? The Academy of Management Executive (1993-2005), 1994. 8(2): p. 83-84.

[54] Latham, S. and M. Braun, Does Short-termism Influence Firm Innovation? An Examination of S\&P 500 Firms, 1990-2003. Journa of Managerial Issues, 2010. 22(3): p. 368-382.

[55] Long, W.F. and D.J. Ravenscraft, LBOs, Debt and R\&D Intensity. Strategic Management Journal, 1993. 14: p. 119-135.

[56] Ughetto, E., Assessing the contribution to innovation of private equity investors: A study on European buyouts. Research Policy, 2010 39(1): p. 126-140.

[57] Datta, S., M. Gruskin, and M. Iskandar-Datta, Lifting the Veil on Reverse Leveraged Buyouts: What Happens During the Private Period? Financial Management, 2013. 42(4): p. 815-842.

[58] Hitt, M.A., et al., Effects of Acquisitions on R\&D Inputs and Outputs. The Academy of Management Journal, 1991. 34(3): p. 693-706.

[59] Nicolas, B., et al., The effects of private equity and buy-outs on HRM in the UK and the Netherlands. Human Relations, 2008. 61(10): p 1399-1433.

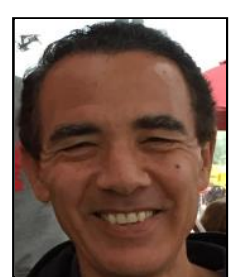

Mr. Israel J. Hersh was born in Tel-Aviv, Israel in 1953. Mr. Hersh is a Ph.D. student in the school of technology management at the University of Bridgeport, CT, USA. Mr. Hersh holds a M.Sc. in electrical and computer engineering from University of Bridgeport, Bridgeport, CT, USA, earned in 1982 and B.Sc.in electrical engineering from Tel-Aviv University, Tel-Aviv, Israel, earned in 1978

$\mathrm{He}$ is also the SVP of Business Development at tekVizion PVS, Plano, TX responsible for Product Management, technology direction, and business development. He is the founder and president of Pirl LLC, a provider of technology consulting to the financial market. He was the Senior Vice President of Product Management and R\&D at IPC Systems and previously the CTO and VP of Engineering at Executone Information Systems.

Mr. Hersh is a member of the Industry Advisory Board (IAB) of University of Bridgeport, CT, USA. 